\title{
Regional Power System Planning Optimization Considering Demand Side Resources
}

\author{
Bo Xu${ }^{1 *}$, Fuqiang Zhang ${ }^{1}$, Hai Huang ${ }^{2}$, Yi Du ${ }^{3}$ \\ ${ }^{1}$ State Grid Energy Research Institute Co., Ltd., Beijing, China \\ ${ }^{2}$ State Grid Fujian Electric Power Co., Ltd., Fuzhou, China \\ ${ }^{3}$ State Grid Fujian Economic Research Institute, Fuzhou, China
}

\begin{abstract}
Power demand side resources include interruptible load and transferable load. With the aid of demand side resources, we can reduce peak load of power system and slow down the power grid investment, and promote the efficiency of power system operation. Based on the assessment of the potential value of demand side resources, this paper proposes a regional power system planning optimization model considering demand side response. The regional total costs of investment cost, fuel cost and demand response compensation cost are minimized with power system planning and operation constraints. The benefits of the proposed model are investigated through several case studies.
\end{abstract}

\section{Introduction}

With the development of society, the problem of energy consumption and environmental pollution becomes more and more serious. The power industry is now faced with the problem of how to improve the efficiency of power production and consumption to meet the increasing demand [1-4]. Due to the acceleration of economic development and the rapid increase in the demand for electricity in the whole society, the installed capacity of new energy is growing rapidly, facing the increasing contradiction between supply and demand, the consumption capacity of the provincial network and other problems. Relying solely on the increase of power supply to meet the needs of the power system has caused certain problems, such as environmental pollution and power grid capacity is difficult to adapt to the increased power generation. Thus, improving the operation efficiency of power system has become inevitable in the future development of power system [5-7].

Improving power system operation efficiency will bring huge economic benefits. This paper considers the influence of demand side resources, and proposes a regional power system planning model to optimize the power units planning in different horizons. The model takes the minimum regional total cost as the optimization objective, and considers the planning and operation constraints of power system.

This paper is composed of five sections. In Section 2, the framework of the proposed model is presented. In Section 3, more details of the model are given. In Section 4, the proposed model is applied to a regional power system. The paper concludes in Section 5.

\section{The framework of the proposed model}

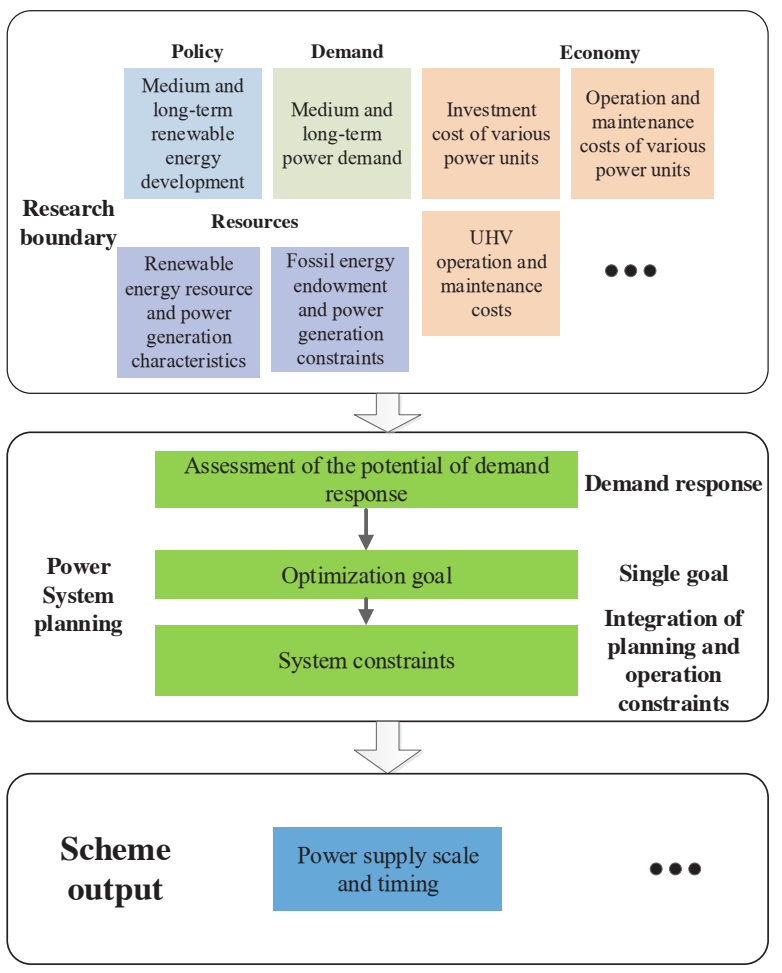

Fig. 1. Framework of the proposed model.

The framework of the proposed model is shown in Fig. 1. First, collect the related data and parameters of the regional power system, including policies, demands and resources.

And then, the potential of demand response in the regional area in the planning horizon is evaluated.

\footnotetext{
* Corresponding author: xubosdu@163.com
} 
Considering the potential of demand response and the characteristics of new energy, a power system planning model is formed, the goal of which is minimizing the total regional system cost.

Finally, the proposed model is used to optimize power units planning.

\section{Formulation of the proposed optimization model}

\subsection{Objective Function}

The objective function is written as

$$
\min \sum_{t=1}^{T}\left[\frac{I_{t}}{(1+r)^{t-1}}+\frac{F_{t}+M_{t}}{(1+r)^{t}}\right]
$$

Where $t$ represents the year. $T$ is the planning horizon. $r$ is the discount rate. $I_{t}, F_{t}$, and $M_{t}$ represent the investment cost, fuel cost, and demand response compensation cost, respectively.

$$
I_{t}=\sum_{m=1}^{M} c_{t, m}^{\mathrm{NG}} \cdot X_{t, m}^{\mathrm{NG}}
$$

Where $M$ represents the types of power generation. $c_{t, m}^{\mathrm{NG}}$ is the investment cost of unit $m . X_{t, m}^{\mathrm{NG}}$ is the installed capacity of unit $m$.

$$
\begin{gathered}
F_{t}=\sum_{m=1}^{M} c f_{t, m} \cdot X P_{t, m}^{\mathrm{G}}, \forall t \\
X P_{t, m}^{\mathrm{G}}=\sum_{j \in J} \pi_{j} \sum_{s=1}^{S} \rho_{t, j, s} \sum_{n=1}^{N_{T}} X P_{t, m, j, s, n}^{\mathrm{G}}, \forall t, m
\end{gathered}
$$

Where $c f_{t, m}$ represents the fuel cost of unit $m . X P_{t, m}^{\mathrm{G}}$ represents the cumulative power generation of unit $m$. $J$ represents a typical day set. $\pi_{j}$ represents the number of days represented by a typical day $j . \rho_{t, j, s}$ represents the probability of new energy generation output scenario $s . S$ is the total number of new energy power generation scenarios. $X P_{t, m, j, s, n}^{\mathrm{G}}$ represents the power generation in period $n . N_{T}$ is the number of periods composed of a typical day.

The demand response compensation cost can be written as

$$
M_{t}=\sum_{d=1}^{D} p_{d t} D_{d t}
$$

Where $p_{d t}$ represents whether demand response $d$ will be implemented in year $t$. $D$ is the types of demand response. $D_{d t}$ represents the compensation cost of demand response $d$.

\subsection{Constraints}

(1) Power balance constraint

$$
\sum_{m=1}^{M} X P_{t, m, j, s, n}^{\mathrm{G}}-X S P_{t, j, s, n}^{\mathrm{G}}-\sum_{d=1}^{D} s_{d t} z_{d t}=D L_{t, j, n}, \forall t, j, s, n \text { (6) }
$$

Where $D L_{t, j, n}$ represents the load demand. $X S P_{t, j, s, n}^{\mathrm{G}}$ represents the energy storage level. $z_{d t}$ represents the reduced peak load by demand response $d$.

(2) Unit output constraint

$\mu_{t, m, j, s}^{\prime \mathrm{G}} X_{t, m}^{\mathrm{G}} \leq X P_{t, m, j, s, n}^{\mathrm{G}} \leq \mu_{t, m, j, s}^{\mathrm{G}} X_{t, m}^{\mathrm{G}}, \forall t, m, j, s, n(7)$

Where $\mu_{t, m, j, s}^{\mathrm{G}}$ and $\mu_{t, m, j, s}^{\prime \mathrm{G}}$ represent the upper and lower limit coefficients of the unit output, respectively. $X_{t, m}^{\mathrm{G}}$ represents the planned installed capacity of the unit $m$ in year $t$.

(3) System backup constraint

$$
\sum_{m=1}^{M} X_{t, m}^{\mathrm{G}} \gamma_{t, m} \geq\left(1+\beta_{t}\right) \cdot M D L_{t}, \forall t
$$

Where $\gamma_{t, m}$ indicates the capacity confidence coefficient of unit $m$. $\beta_{t}$ indicates the system back up coefficient. $M D L_{t}$ is peak power load of year $t$.

\section{Case studies}

An illustrative study is conducted on a regional power system in this section to demonstrate how the proposed model works. The system data are given in Table 1. The parameters of coal-fired units, gas-fired units, hydro units, pumped storage units, energy storage, biomass generating units, wind power units and photovoltaic units are considered as the national average. According to the development trend, the parameter values in the medium and long-term are predicted.

Table 1. The system data.

\begin{tabular}{|c|c|c|c|}
\hline Units & $\begin{array}{c}\text { Investment } \\
\text { (yuan/kW) }\end{array}$ & $\begin{array}{c}\text { Fixed } \\
\text { cost }\end{array}$ & $\begin{array}{c}\text { Fuel price } \\
\text { (yuan/ ton of } \\
\text { standard coal) }\end{array}$ \\
\hline Coal-fired unit & 3156 & $2 \%$ & 680 \\
\hline Gas-fired unit & 3063 & $4 \%$ & 2000 \\
\hline Hydro unit & 11272 & $2 \%$ & 0 \\
\hline $\begin{array}{c}\text { Pumped } \\
\text { storage unit }\end{array}$ & 4000 & $2 \%$ & 0 \\
\hline $\begin{array}{c}\text { Energy } \\
\text { storage }\end{array}$ & 10050 & $2 \%$ & 0 \\
\hline $\begin{array}{c}\text { Biomass } \\
\text { generating } \\
\text { unit }\end{array}$ & 10000 & $2 \%$ & 8 \\
\hline $\begin{array}{c}\text { Wind power } \\
\text { unit }\end{array}$ & 8356 & $1 \%$ & 0 \\
\hline $\begin{array}{c}\text { Photovoltaic } \\
\text { unit }\end{array}$ & 8225 & $1 \%$ & 0 \\
\hline
\end{tabular}

Table 2 presents an assessment of the market potential of demand response for the year 2025 and 2035 The Table shows that the market potential of demand response resources in the region will reach 30.55 megawatts by 2025. By 2035, the market potential of demand response resources will reach 45.84 megawatts . 
Table 2. Market potential of demand response (megawatts).

\begin{tabular}{|c|c|c|}
\hline \multirow{2}{*}{ Type of demand response } & \multicolumn{2}{|c|}{$\begin{array}{c}\text { Market potential of } \\
\text { demand response }\end{array}$} \\
\hline & 2025 & 2035 \\
\hline $\begin{array}{l}\text { Ferrous metal smelting and } \\
\text { calendering processing industry }\end{array}$ & 1.80 & 2.02 \\
\hline $\begin{array}{l}\text { Nonferrous metal smelting and } \\
\text { calendaring processing industry }\end{array}$ & 7.95 & 8.26 \\
\hline $\begin{array}{c}\text { Non-mental mineral product } \\
\text { industry }\end{array}$ & 6.20 & 9.15 \\
\hline $\begin{array}{l}\text { Chemical raw material product } \\
\text { manufacturing industry }\end{array}$ & 2.00 & 3.02 \\
\hline $\begin{array}{l}\text { Agricultural supplementary } \\
\text { foodstuff processing industry }\end{array}$ & 2.45 & 4.76 \\
\hline Food manufacturing industry & 2.66 & 5.17 \\
\hline $\begin{array}{l}\text { Alcohol, beverage and refining } \\
\text { tea manufacting industry }\end{array}$ & 0.16 & 0.23 \\
\hline Textile industry & 3.28 & 4.11 \\
\hline $\begin{array}{l}\text { Woodworking and wood, } \\
\text { bamboo, ratten, palm and grass } \\
\text { product industry }\end{array}$ & 0.50 & 0.61 \\
\hline $\begin{array}{l}\text { Papermaking and paper } \\
\text { product industry }\end{array}$ & 0.48 & 0.68 \\
\hline $\begin{array}{l}\text { General equipment } \\
\text { manufacting industry }\end{array}$ & 2.12 & 3.76 \\
\hline Wholesale and retailing & 0.25 & 1.26 \\
\hline Lodging and catering industry & 0.15 & 0.79 \\
\hline Urban and rural residents & 0.55 & 2.02 \\
\hline Total & 30.55 & 45.84 \\
\hline
\end{tabular}

In order to illustrate the effectiveness of the proposed model, two case studies are conducted. In Case 1, the influence of demand response on power system planning is considered, while in Case 2, demand side response is neglected. The optimization results obtained in Case 1 are summarized in Table 3. We can see that, in 2025, the total power generation capacity in the region will reach 11.8 million kilowatts, of which 6.94 million kilowatts are coal-fired units, accounting for $59 \%$. New energy will develop rapidly, wind power and photo voltaic units will reach 3.3 million kilowatts, accounting for $28 \%$. In 2035, the total installed capacity will reach 16.17 million kilowatts, of which 9.26 million kilowatts are coal-fired units, accounting for $57 \%$. Wind power and photo voltaic units will reach 4.82 million kilowatts.

Table 3. Power supply structure in Case 1(million kilowatts)

\begin{tabular}{|c|c|c|}
\hline \multirow{2}{*}{ Units } & \multicolumn{2}{|c|}{ Installation capacity } \\
\cline { 2 - 3 } & 2025 & 2035 \\
\hline Coal-fired unit & 6.94 & 9.26 \\
\hline Gas-fired unit & 0.34 & 0.49 \\
\hline Hydro unit & 0.26 & 0.27 \\
\hline Wind power unit & 1.87 & 2.44 \\
\hline Pumped storage unit & 0.48 & 0.57 \\
\hline
\end{tabular}

\begin{tabular}{|c|c|c|}
\hline Energy storage & 0.19 & 0.38 \\
\hline Photovoltaic unit & 1.43 & 2.38 \\
\hline $\begin{array}{c}\text { Biomass generating } \\
\text { unit }\end{array}$ & 0.29 & 0.38 \\
\hline Total & 11.8 & 16.17 \\
\hline
\end{tabular}

The comparisons of Case 1 and Case 2 are shown in Table 4 and Table 5.

Table 4. Comparison of different cases

\begin{tabular}{|c|c|c|c|c|}
\hline \multirow{2}{*}{ Cases } & \multicolumn{2}{|c|}{$\begin{array}{c}\text { Capacity /million } \\
\text { kilowatts }\end{array}$} & \multicolumn{2}{c|}{$\begin{array}{c}\text { Average generating } \\
\text { equipment availability hours }\end{array}$} \\
\cline { 2 - 5 } & 2025 & 2035 & 2025 & 2035 \\
\hline Case 1 & 11.8 & 16.17 & 3247 & 4079 \\
\hline Case 2 & 12.12 & 16.65 & 3160 & 3960 \\
\hline
\end{tabular}

Table 5. Comparison of costs in different cases (billion yuan)

\begin{tabular}{|c|c|c|c|c|}
\hline Cases & $\begin{array}{c}\text { Investment } \\
\text { cost }\end{array}$ & $\begin{array}{c}\text { Fuel } \\
\text { cost }\end{array}$ & $\begin{array}{c}\text { Demand } \\
\text { response } \\
\text { cost }\end{array}$ & Total cost \\
\hline Case 1 & 40.49 & 74.73 & 0.08 & 115.3 \\
\hline Case 2 & 42.44 & 74.93 & 0 & 117.37 \\
\hline
\end{tabular}

From Table 4 and Table 5, we can see that:

(1) In Case 1, the average generating equipment availability hours in 2025 and 2035 are 3247 hours and 4079 hours, respectively, which increased significantly compared with that of Case 2. In this case, the operation efficiency of power system is improved compared with Case 2.

(2) In Case 2, to meet the system planning and operation constraints, the system installed capacity must be increased compared with Case 1. Although the demand response compensation cost is reduced by 0.08 billion yuan, the investment cost and fuel cost are increased, and the total cost is increased by 2.07 billion yuan.

\section{Conclusions}

This paper proposes a regional power system planning optimization model. The model considers characteristics and potential of power demand response, and takes the total regional cost as the optimization goal. The case studies show that the implementation of demand response can significantly reduce total regional cost and improve operation efficiency of power system. Therefore, the demand side management should be strengthened in the future.

\section{Acknowledgement}

This work is supported by the State Grid science and technology research project "Research on Provincial 
Energy System Optimization Model and Application under the Background of Modern Energy Economy" (Grant SGFJJY00GHJS1900003).

\section{References}

1. Gellings $\mathrm{C} \mathrm{W}$. Then and now : The perspective of the man who coined the term 'DSM' $[\mathrm{J}]$. Energy Policy, 1996, 24(4): 285-288.

2. Moghaddas Tafreshi S M, Saliminia Lahiji A. Longterm market equilibrium in smart grid paradigm with introducing demand response provider in competition [J]. IEEE Transactions on Smart Grid, 2015, 6(6): 2794-2806.

3. Bao Zhejing, Zhou Qin, Yang Zhihui, et al. A multi time-scale and multi energy-type coordinated microgrid scheduling solution-Part I : model and methodology [J]. IEEE Transactions on Power Systems, 2015, 30(5): 2257-2266.

4. Sheikhi A, Bahrami S, Ranjbar A M. An autonomous demand response program for electricity and natural gas networks in smart energy hubs[J]. Energy, 2015, 89: 490-499.

5. Paterakis N G, Erdinç $O$, Catalão J P S. An overview of Demand Response : Key-elements and international experience[J]. Renewable and Sustainable Energy Reviews, 2017, 69: 871-891.

6. Tsui K M, Chan S C. Demand response optimization for smart home scheduling under realtime pricing[J]. IEEE Transactions on Smart Grid, 2012, 3(4): 1812-1821.

7. Alipour M, Mohammadi-Ivatloo B, Zare K. Stochastic risk-constrained short-term scheduling of industrial cogeneration systems in the presence of demand response programs[J]. Applied Energy, 2014, 136: 393-404. 